\title{
Assessment of the Presence of Resistance Genes Detected from the Environment and Selected Food Products in Benin
}

\author{
Victorien Dougnon $\mathbb{D}^{1},{ }^{1}$ Vincentia Marie Camille Houssou, ${ }^{2}$ Eugénie Anago, ${ }^{1}$ \\ Chimène Nanoukon, ${ }^{3}$ Jibril Mohammed, ${ }^{4}$ Jerrold Agbankpe $\left(\mathbb{0},{ }^{1}\right.$ Hornel Koudokpon $\left(\mathbb{0},{ }^{1}\right.$ \\ Birikissou Bouraima, ${ }^{1}$ Esther Deguenon, ${ }^{1}$ Kafayath Fabiyi, ${ }^{1}$ Marie Hidjo, ${ }^{1}$ Fidélia Djegui, ${ }^{5}$ \\ Lamine Baba-Moussa $\mathbb{D}^{\mathrm{D}}{ }^{6}$ and Martin Pépin Aïna ${ }^{2}$ \\ ${ }^{1}$ Research Unit in Applied Microbiology and Pharmacology of Natural Substances, Research Laboratory in Applied Biology, \\ Polytechnic School of Abomey-Calavi, University of Abomey-Calavi, P. O. Box 2009, Cotonou, Benin \\ ${ }^{2}$ Laboratory of Monitoring and Environmental Studies, Ministry of the Living Environment and Sustainable Development, Benin \\ ${ }^{3}$ Laboratory of Molecular Biology and Bioinformatics Applied to Genomics, \\ National School of Biosciences and Applied Biotechnologies, \\ National University of Sciences, Technologies, Engineering and Mathematics, Abomey, Benin \\ ${ }^{4}$ Department of Microbiology, Parasitology and Biotechnology, College of Veterinary Medicine and Biomedical Sciences, \\ Sokoine University of Agriculture, Morogoro, Tanzania \\ ${ }^{5}$ Laboratory of Veterinary Diagnosis and Serosurveillance of Parakou, Ministry of Agriculture, Livestock and Fisheries, \\ Parakou, Benin \\ ${ }^{6}$ Laboratory of Biology and Molecular Typing in Microbiology, Faculty of Science and Technology, \\ University of Abomey-Calavi, UAC, P. O. Box 1604, Cotonou, Benin
}

Correspondence should be addressed to Victorien Dougnon; victorien88@hotmail.com

Received 7 June 2020; Revised 15 December 2020; Accepted 13 January 2021; Published 4 February 2021

Academic Editor: John Yabe

Copyright (c) 2021 Victorien Dougnon et al. This is an open access article distributed under the Creative Commons Attribution License, which permits unrestricted use, distribution, and reproduction in any medium, provided the original work is properly cited.

\footnotetext{
Gram-negative bacilli can spread from the environment and through food products. This study aimed to characterize ESBL production and virulence genes from multidrug-resistant Gram-negative bacilli isolated from specimen collected from the environment, kitchen, and food products. A total of 130 samples were collected at local markets in seven different communities in Benin (Abomey-Calavi, Ouidah, Bohicon, Abomey, Parakou, Djougou, and Grand-Popo). Samples were cultured on McConkey and ChromID ${ }^{\mathrm{rm}}$ ESBL agar plates. The isolates were identified by the API 20E gallery. An antibiotic susceptibility test was carried out, and the detection of ESBL production and virulence-associated genes was carried out by Polymerase Chain Reaction (PCR). The data collected was coded and analyzed using GraphPad prism 7 software and Excel. The software R was used to calculate the correlation coefficient between the results of the detection of ESBL+ on agar and by the effect of the double synergy. The results showed that sixty-three (63) bacterial strains were isolated from the 130 samples, of which the dominant species was Chryseomonas luteola (10/63). The kitchen samples were the most contaminated with $36.50 \%$. More than $40 \%$ of the isolates were resistant to at least three different classes of antibiotics. Also, blaSHV gene was detected in $33.33 \%(21 / 63)$ of the isolates and in all isolates of Pseudomonas aeruginosa (5/5\%). 11.11\% (7/63) of isolates were virulent with dominance of the fim $\mathrm{H}$ gene, especially with Escherichia coli (83.33\%). The kitchen samples showed a high prevalence of ESBL-producing strains with fim $\mathrm{H}$ gene. This raises the problem of non-compliance with hygiene rules in community cooking and food handling.
} 


\section{Introduction}

Antimicrobial resistance has become a major threat to global public health in the $21^{\text {st }}$ century [1]. It is estimated that, by 2050, 10 million deaths per year and up to $\$ 100$ trillion of global economic loss will occur if the problem of antimicrobial resistance is not immediately resolved [2]. In recent years, in the Enterobacteriaceae family in particular, there has been increasing evidence of a high prevalence of multiresistant Gram-negative bacteria. The use of antibiotics in human medicine, veterinary medicine, and agriculture has been the main selective pressure for the emergence of drugresistant bacteria [3].

The emergence and rapid spread of extended spectrum $\beta$-lactamase- (ESBL-) producing bacteria poses a threat to the population, not only in developing countries, but also in developed countries, as ESBLs may degrade not only penicillin, but also other classes of $\beta$-lactams. In addition, most ESBL-producing bacteria are multiresistant [4]. The increased presence of Enterobacteriaceae producing ESBL in non-clinical environments such as food, animal husbandry, and agriculture and in different aquatic environments has been shown in several studies [5-7]. In addition, multiresistant enterobacteria have been isolated from healthy individuals [8], suggesting that the community may serve as a reservoir. It is known that the intestinal tract is an excellent reservoir for these bacteria and that colonized people may be infected later. In fact, the presence of Escherichia coli producing CTX-M has been reported in healthy children [9], which shows the potential risk of spreading $\beta$-lactamasemediated resistance.

The dissemination of $\beta$-lactamase-encoding genes in different geographical regions may partly be due to the fact that many resistance genes are carried on selftransmissible or mobile plasmids capable of spreading horizontally between and within species [3]. During gene transfer, resistance mechanism to other classes of antibiotics can easily be combined [10]. There are different types of $\beta$-lactamase enzymes present in bacteria inhabiting diverse environments and exposed to different selection pressures [11]. The virulence factors of Enterobacteria have an important role in the development of infections [12]. The molecular characteristics and functions of these virulence factors have been determined [13]. The most likely theory is that strains of pathogenic enterobacteria evolved primarily from non-pathogenic strains by acquiring virulence genes (by horizontal transfer of plasmid, bacteriophage, transposon, and pathogenicity located at chromosomal loci), which provides increased adaptive capacity to new niches and allows pathogens to increase their ability to cause wide range of infections [14, 15]. Moreover, evolution of virulence and resistance occurred at different time points. Virulence has evolved over millions of years, but resistance is a new phenomenon that has occurred over the past few decades (after introduction of antibiotics). As aquatic bacterial genetic reactors, aquatic environments promote the transmission of resistance genes virulence, and virulencerelated characteristics among bacterial strains [16].
In Benin, several studies have reported the increasing evolution of the prevalence of broad-spectrum $\beta$-lactamase-producing enterobacteria in clinical infections [17-19]. But few studies have reported broad-spectrum $\beta$-lactamase-producing bacteria isolated simultaneously from external environment, kitchen environment, and food products. The current study is aimed at providing scientific knowledge regarding the spread of broad-spectrum $\beta$-lactamase-producing enterobacteria in different environments in Benin, and also at characterizing the resistance genes and determining their virulence factors. Such data will be used to better understand clinically observed antibiotic resistance. The study will also serve as a basis for recommendations to combat antibiotic resistance.

\section{Material and Methods}

2.1. Zone and Period of Study. The study was carried out mainly in the South of Benin, and in some towns in Northern Benin. ${ }^{2}$. In Southern Benin, the average annual temperature is $28^{\circ} \mathrm{C}$ and the humidity varies between 69 and 97\% [19]. The phytogeographic districts covered by this study are Coastal, Pobè, Ouémé valley, Plateau, Zou, Borgou, and Donga. The study was done in December 2020. The samples were collected from community kitchen environment (cloth, sink, sponge, soap, and bench), external environments (sediment/mud, sewage, feces of animal's cattle, pig, and chicken), and foods products (crabs, fresh shrimps, dried fishes, fermented fishes, tomatoes, and leafy vegetable) (Figure 1).

2.2. Collection of Samples. Sampling was done randomly, depending on sample availability. Thirty (30) samples from the community kitchen environment were collected by swabbing. Thirty (30) sediments/mud, nine (9) animal feces, and forty-two (42) food products were collected in sterile stomach bags. Nineteen (19) sewage samples were collected in sterile one-liter bottles. A total of 130 samples were collected from the local markets of Dantokpa, Grand-Popo, Abomey-Calavi, the University of Abomey-Calavi, Bohicon, Abomey, Parakou, and Djougou (Table 1).

\subsection{Bacteriological Analysis}

\subsubsection{Seeding}

Sewage Samples. After homogenization, $1 \mathrm{ml}$ of each sample was taken and added to $9 \mathrm{ml}$ of sterile distilled water contained in a screw tube for the preparation of $10^{-1}$ dilution. Successive decimal dilutions were made up to $10^{-3}$ and $100 \mu \mathrm{l}$ of each dilution was then inoculated on McConkey and ChromID $^{\mathrm{TM}}$ ESBL solid media (Biomerieux, France).

Solid Samples. Previously, all food samples were ground in a sterile mortar. $9 \mathrm{ml}$ of sterile distilled water was added to $1 \mathrm{~g}$ of each solid sample (sediment/sludge, animal feces, and crushed food item) contained in a screw tube (stock solution). After homogenization through a vortex, $1 \mathrm{ml}$ of the 


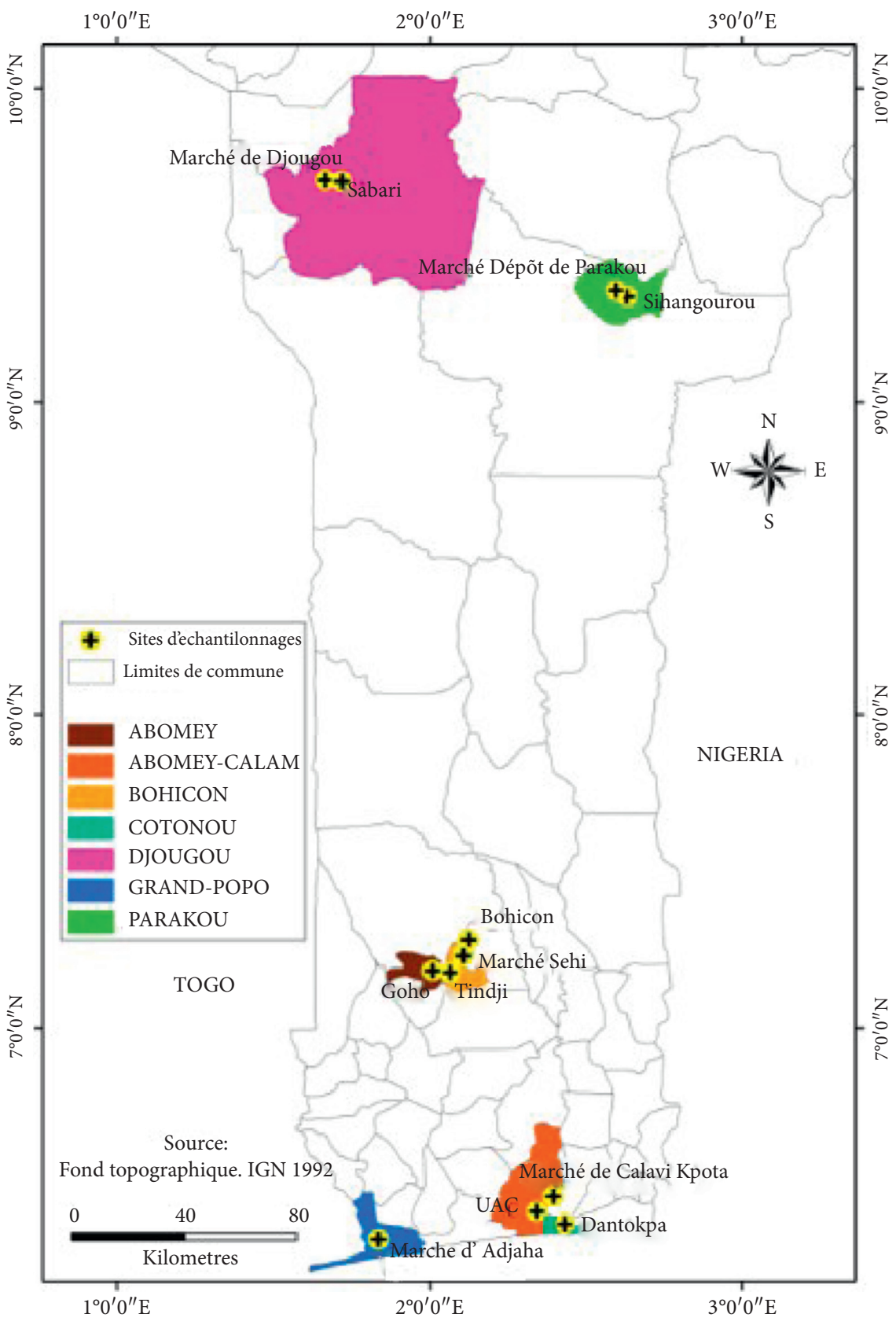

FIGURE 1: Location map of collection's areas.

stock solution $\left(10^{-1}\right.$ dilution) was added again to $9 \mathrm{ml}$ of distilled water $\left(10^{-2}\right.$ dilution). Successive decimal dilutions were made up to $10^{-4}$. The last three dilutions $\left(10^{-2}, 10^{-3}\right.$, and $10^{-4}$ ) were then seeded on McConkey solid media and ChromID $^{\mathrm{TM}}$ ESBL (Biomerieux, France).

Community Kitchen Samples. Each community kitchen sample swab was cultured on McConkey and ChromID ${ }^{\mathrm{TM}}$ ESBL solid media by streaking with sterile loop (Biomerieux, France).

2.4. Incubation. All previously prepared McConkey and ChromID $^{\text {Thx }}$ ESBL agars (Biomerieux, France) were incubated at $37^{\circ} \mathrm{C}$ for $24 \mathrm{~h}$.
2.5. Biochemical Identification. After $24 \mathrm{~h}$ incubation, Gram staining was performed on all characteristic colonies on McConkey. Each selected characteristic colony (Gramnegative bacillus) was removed and seeded on MuellerHinton solid medium (MH). The $\mathrm{MH}$ agar plates were then incubated at $37^{\circ} \mathrm{C}$ for $24 \mathrm{~h}$. Gram controls, oxidase test, and the identification by the gallery API20E tests were made after.

2.6. Susceptibility of Strains to Antibiotics. An antibiogram was performed for each bacterial sample isolated by method of disk diffusion using Mueller-Hinton agar II medium in accordance with the recommendations of the Antibiogram 
TABLE 1: Distribution of samples according to their nature and origin.

\begin{tabular}{|c|c|c|c|}
\hline Sample origin & Type of sample & Location & Positive samples \\
\hline \multirow{5}{*}{ Community kitchens } & Cloth & Abomey-Calavi & 6 \\
\hline & Sink & Abomey-Calavi & 12 \\
\hline & Bench & Abomey-Calavi & 3 \\
\hline & Sponge & Abomey-Calavi & 6 \\
\hline & Soap & Abomey-Calavi & 3 \\
\hline \multirow{10}{*}{ Sediments/muds } & Sediment of waste water (from Kpahou's farm) & Ouidah & 3 \\
\hline & Gutter sediment & Abomey-Calavi street & 6 \\
\hline & Lake sediment & Abomey-Calavi market & 6 \\
\hline & Mud & Grand-Popo market & 3 \\
\hline & Sediment of little beach & Grand-Popo & 6 \\
\hline & Sinangourou bridge waste water's sediment & Sinangourou, Parakou & 1 \\
\hline & Sewage sediment from the Sabari drainage canal & Sabari, Djougou & 2 \\
\hline & Drainage canal crossing Abomey & Goho, Abomey & 1 \\
\hline & Drainage canal crossing Bohicon & Bohicon & 1 \\
\hline & Drainage canal crossing Tindji & Tindji & 1 \\
\hline \multirow{7}{*}{ Sewage } & Water from River & Grand-Popo & 3 \\
\hline & Sewage from market & Abomey-Calavi & 3 \\
\hline & Sewage from market & Dantokpa (Cotonou) & 3 \\
\hline & Sewage from market & Grand-Popo & 3 \\
\hline & Sewage from University of Abomey-Calavi & Abomey-Calavi & 3 \\
\hline & Sinangourou bridge's waste water & Parakou, Sinangourou & 1 \\
\hline & Waste water drainage system crossing Djougou & Sabari, Djougou & 2 \\
\hline \multirow{3}{*}{ Feces of animals } & Feces of cattle from market & Grand-Popo & 3 \\
\hline & Feces of pig from market & Grand-Popo & 3 \\
\hline & Feces of chicken from market & Grand-Popo & 3 \\
\hline \multirow{14}{*}{ Foods } & Crabs from market & Grand-Popo & 3 \\
\hline & Leafy vegetable from market & Grand-Popo & 3 \\
\hline & Fresh shrimp from market & Grand-Popo & 3 \\
\hline & Dried fishes from market & Grand-Popo & 3 \\
\hline & Fresh tomatoes from market & Grand-Popo & 3 \\
\hline & Fresh shrimp from market & Dantokpa (Cotonou) & 3 \\
\hline & Dried fishes from market & Dantokpa (Cotonou) & 3 \\
\hline & Fermented fishes from market & Dantokpa (Cotonou) & 3 \\
\hline & Fresh tomatoes from market & Dantokpa (Cotonou) & 3 \\
\hline & Fresh tomatoes from market & Djougou & 4 \\
\hline & Dried fishes from market & Abomey & 3 \\
\hline & Leafy vegetable from market & Parakou & 4 \\
\hline & Soja cheese & Bohicon & 5 \\
\hline & Total & & 130 \\
\hline
\end{tabular}

Committee of the French Society of Microbiology [20]. The antibiotics tested against the isolates were amoxicillin (AMX) $(25 \mu \mathrm{g})$, gentamicin (GEN) $(10 \mu \mathrm{g})$, ceftriaxone (CRO) $(30 \mu \mathrm{g})$, cefotaxime (CTX) $(30 \mu \mathrm{g})$, ertapenem (ETP) $(10 \mu \mathrm{g})$, imipenem (IPM) $(10 \mu \mathrm{g})$, ciprofloxacin (CIP) $(5 \mu \mathrm{g})$, amoxicillin + clavulanic acid (AMC) $(30 \mu \mathrm{g})$, and aztreonam (ATM) $(30 \mu \mathrm{g})$. They were acquired from Sigma Aldrich.

The reference strain (E. coli ATCC 25923) and the strains to be tested were previously subcultured on the $\mathrm{MH}$ agar and incubated for $24 \mathrm{~h}$ at $37^{\circ} \mathrm{C}$ in order to provide young colonies. For each strain inoculum correspondent standard McFarland 0.5 was prepared. Using a sterile swab, the inoculum obtained was cultured by swabbing on dried MH II medium. The spreading was rotated three times in order to obtain a homogeneous distribution of the inoculum. The pre-impregnated antibiotic discs were then gently deposited on the surface of the agar with a disc dispenser. The agar plates were incubated for $24 \mathrm{~h}$ at $37^{\circ} \mathrm{C}$.
A double disc diffusion method was used for the phenotypic confirmation of ESBL production according to the guidelines described by the Clinical Laboratory Standards Institute [21]. Klebsiella pneumonia (ATCC 700603) was used as the standard strain.

\subsection{Molecular Detection of Virulence-Associated and ESBL} Genes. The DNA of all isolates was extracted using the Qiagen red extraction kit. The isolates were tested for different virulent genes using standard PCR with six sets of specific primer pairs (Table 2). The reaction mixture consisted of $9.5 \mu \mathrm{L}$ of water without DNA, $12.5 \mu \mathrm{L}$ of the 2 XPCR Master Mix reagent, $0.5 \mu \mathrm{L}$ of each primer pair, and $2 \mu \mathrm{L}$ of bacterial DNA.

The virulence genes that were targeted for amplification by PCR were iss, fim $\mathrm{H}$, Stx-1, Stx-2, biofilm, and PapC, whereas the ESBL genes targeted for amplification were blaTEM, blaSHV, blaCTX-M1, blaCTX-M2, blaCTX-M9, and blaCTX-M15. 
TABLE 2: Primers of virulence genes and desired ESBL genes in the genome of isolates.

\begin{tabular}{|c|c|c|c|c|}
\hline Genes & Primer & Sequence (5'-3') & Amplicon size (bp) & Reference (s) \\
\hline \multicolumn{5}{|l|}{ Virulence } \\
\hline \multirow{2}{*}{ PapC } & $\mathrm{F}$ & GACGGCTGTACTGCAGGGTGGCG & \multirow[b]{2}{*}{328} & \\
\hline & $\mathrm{R}$ & ATATCCTTTCTGCAGGGATGCAATA & & \\
\hline \multirow{2}{*}{$f i m \mathrm{H}$} & $\mathrm{F}$ & TACTGCTGATGGGCTGGTC & \multirow{2}{*}{640} & \\
\hline & $\mathrm{R}$ & GCCGGAGAGGTAATACCCC & & \\
\hline \multirow{2}{*}{ iss } & $\mathrm{F}$ & GGCAATGCTTATTACAGGATGTGC & \multirow{2}{*}{260} & \\
\hline & $\mathrm{R}$ & GAGCAATATACCCGGGCTTCC & & \\
\hline \multirow{2}{*}{ Biofilm } & $\mathrm{F}$ & GATTCAATTTTGGCGATTCCTGC & \multirow{2}{*}{225} & [3] \\
\hline & $\mathrm{R}$ & TAATGAAGTCATTCAGACTCATCC & & \\
\hline \multirow{2}{*}{ Stx1 } & $\mathrm{F}$ & CGCTGAATGTCATTCGCTCTGC & \multirow{2}{*}{302} & \\
\hline & $\mathrm{R}$ & CGTGGTATAGCTACTGTCACC & & \\
\hline \multirow{2}{*}{ Stx2 } & $\mathrm{F}$ & CCTCGGTATCCTATTCCCGG & \multirow[b]{2}{*}{516} & \\
\hline & $\mathrm{R}$ & CTGCTGTGACAGTGACAAAACGC & & \\
\hline \multicolumn{5}{|c|}{ ( } \\
\hline \multirow{2}{*}{ bla ${ }_{\text {CTX-M1 }}$} & $\mathrm{F}$ & GGTTAAAAAATCACTGCGTC & \multirow{2}{*}{863} & \\
\hline & $\mathrm{R}$ & TTGGTGACGATTTTAGCCGC & & \\
\hline \multirow{2}{*}{ bla $_{\text {CTX-M2 }}$} & $\mathrm{F}$ & ATGATGACTCAGAGCATTCG & \multirow{2}{*}{865} & \\
\hline & $\mathrm{R}$ & TGGGTTACGATTTTCGCCGC & & \\
\hline \multirow{2}{*}{ bla } & $\mathrm{F}$ & ATGGTGACAAAGAGAGTGCA & \multirow{2}{*}{869} & \\
\hline & $\mathrm{R}$ & CCCTTCGGCGATGATTCTC & & {$[4]$} \\
\hline \multirow{2}{*}{ bla $_{\text {CTX-M15 }}$} & $\mathrm{F}$ & CACACGTGGAATTTAGGGACT & \multirow{2}{*}{995} & {$[4]$} \\
\hline & $\mathrm{R}$ & GCCGTCTAAGGCGATAAACA & & \\
\hline \multirow{2}{*}{ bla $_{\mathrm{TEM}}$} & $\mathrm{F}$ & ATGAGTATTCAACATTTCCGC & \multirow[b]{2}{*}{856} & \\
\hline & $\mathrm{R}$ & CAATGCTTAATCAGTGAGG & & \\
\hline \multirow{2}{*}{ bla $_{\mathrm{SHV}}$} & $\mathrm{F}$ & AAGATCCACTATCGCCAGCAG & \multirow{2}{*}{230} & \\
\hline & $\mathrm{R}$ & ATTCAGTTCCGTTTCCCAGCGG & & \\
\hline
\end{tabular}

The amplification of bla $\mathrm{TEM}_{\mathrm{TE}}$, bla $\mathrm{SHV}_{\mathrm{S}}$, bla $\mathrm{CTX}_{\mathrm{C} 1 \mathrm{M}}$, bla $\mathrm{C}_{\mathrm{CTX}-}$

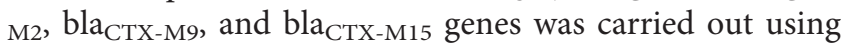
the method described in $[22,23]$. The amplification of fimH and iss genes was performed using the method described in [24]. Regarding PapC gene, its amplification was also carried out using the method previously described in [25]. The amplification conditions of the other genes (Stx-1, Stx-2, and Biofilm) involved initial denaturation at $94^{\circ} \mathrm{C}$ for $30 \mathrm{sec}$, followed by 30 cycles at $94^{\circ} \mathrm{C}$ for 30 secs of denaturation at $68^{\circ} \mathrm{C}$ for $1 \mathrm{~min}$ of hybridization, at $68^{\circ} \mathrm{C}$ elongation for $1 \mathrm{~min}$. Final extension was carried out at $68^{\circ} \mathrm{C}$ for $5 \mathrm{~min}$ and maintained at $4^{\circ} \mathrm{C}$. Amplification products were separated by $2 \%$ agarose gel electrophoresis with $5 \mu \mathrm{g} / \mathrm{ml}$ red gel and a $100 \mathrm{bp}$ DNA ladder as a molecular weight marker. The migration was carried out at a scale of $90 \mathrm{~V} / \mathrm{cm}$ for $20 \mathrm{~min}$. Amplification bands were visualized and photographed under ultraviolet light (UV).

2.8. Statistical Analyses. The data collected was coded and analyzed using GraphPad prism 7 software. Phenotypic identification methods were performed independently in triplicate. The software $\mathrm{R}$ was used to calculate the correlation coefficient between the results of the detection of $\mathrm{ESBL}+$ on agar and by the effect of the double synergy.

\section{Results}

3.1. Culture on McConkey Agar. Of the 130 samples analyzed, we were able to isolate 63 bacterial strains, all Gramnegative bacilli. The kitchen environment samples contained
$36.50 \%(23 / 63)$ of the isolated bacterial strains, followed by external environmental samples (33.33\%) (21/63) whereas the samples from food products were $30.15 \%$ (19/63).

3.2. Culture on ChromID ${ }^{\mathrm{TM}}$ ESBL Agar. Samples were cultured on both McConkey Agar and ChromID ${ }^{\mathrm{TM}}$ ESBL Agar. The latter provided us with preliminary data on strains that produce $\beta$-lactamase. Of the 130 samples analyzed, 21 $\beta$-lactamase-producing strains were isolated. Furthermore, $47.61 \% \beta$-lactamase-producing strains were isolated from community kitchen samples, $42.85 \%$ from external environmental samples, and $9.52 \%$ from food products.

3.3. Identification of Isolates. After isolation, a total of 63 strains were identified and there were about 21 bacterial species. As shown in Figure 2, there is a dominance of Chryseomonas luteola (10/63), followed by Pseudomonas oryzihabitans (6/63), Enterobacter cloacae (6/63), and E. coli (6/63).

3.4. Antimicrobial Susceptibility. Table 3 shows the details of the antibiotic resistance profile of the identified strains. Of the 63 isolates, 59 (93.65\%) were resistant to Amoxicillin and $54(85.71 \%)$ to Cefotaxime, with relatively low resistance to Imipenem (16) (25.39\%), Gentamicin (9) (14.28\%), and Ciprofloxacin (5) (7.93\%). The multidrug resistance analysis of the strains showed that there were $27.57 \%$ isolates that were resistant to at least 5 antibiotics, $19.95 \%$ isolates resistant to 4 antibiotics, and $16.81 \%$ isolates resistant to 3 antibiotics. We noted that there are two isolates, $P$. 


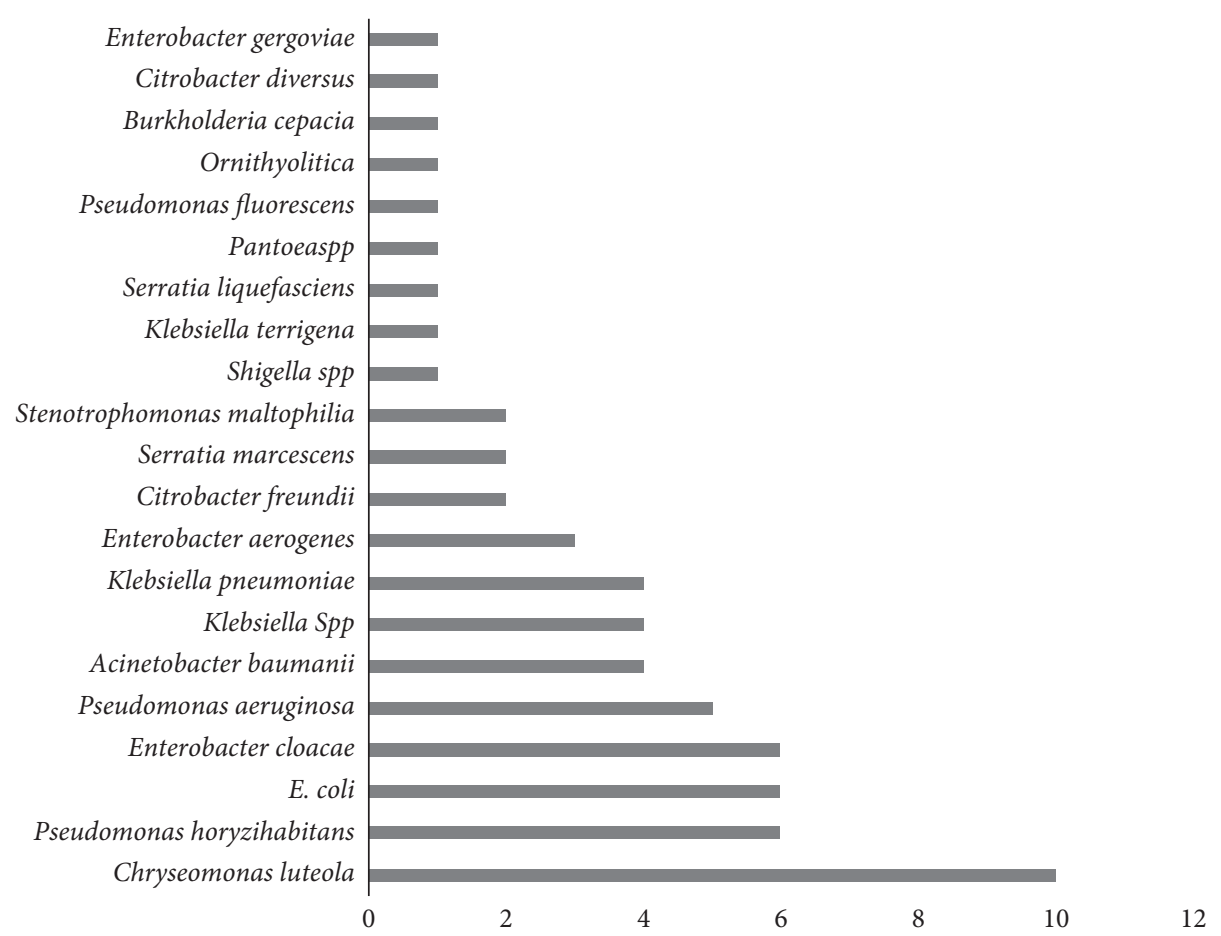

FIGURE 2: Distribution of isolated bacterial species.

TABle 3: Antimicrobial susceptibility profiles of isolates.

\begin{tabular}{lc}
\hline Antibiotics & \% of resistance \\
\hline Ceftriaxone (CRO) & 52.38 \\
Cefotaxime (CTX) & 85.71 \\
Amoxicillin (AMX) & 93.65 \\
Gentamicin (GEN) & 14.28 \\
Ciprofloxacin (CIP) & 7.93 \\
Imipenem (IPM) & 25.39 \\
Ertapenem (ETP) & 61.90 \\
Amoxicillin + clavulanic acid (AMC) & 57.14 \\
Aztreonam (ATM) & 44.44 \\
\hline
\end{tabular}

aeruginosa and P. fluorescens, that were resistant to all 9 antibiotics tested.

3.5. PCR Detection of Virulence-Associated Genes of Isolates. Six genes (iss, fim $\mathrm{H}$, st $x 1$, st $x 2$, biofilm, and $P a p C$ ) of virulence were investigated in the genome of the 63 identified isolates. Only the fimH gene was detected as indicated in Table 4. Figure 3(a) shows the agarose gel of fim $\mathrm{H}$ after PCR.

3.6. PCR Detection of ESBL Genes of Isolates. Of six ESBL genes (bla $\mathrm{T}_{\mathrm{TEM}}$, bla $\mathrm{SHV}_{\mathrm{SHV}}$, bla $\mathrm{CTX}_{\mathrm{CT} 1}$, bla $\mathrm{CTX}_{\mathrm{CT}}$, bla $\mathrm{C}_{\mathrm{CTX}-\mathrm{M} 9}$, and bla $_{\text {CTX-M15), only the Bla }}$ SHV gene was found in the genome of 21 isolates. These isolates comprised Pseudomonas aeruginosa (100\%) (5/5), followed by Pseudomonas fluorescens (100\%) (1/1) and K. pneumoniae (75\%) (3/4). All the strains isolated on ChromID ${ }^{\mathrm{TM}}$ ESBL agar and whose double synergy was observed during antibiotic susceptibility tests were also positive for the detection of the bla $\mathrm{SHV}_{\mathrm{H}}$ gene $(r=1$, $P<0.001)$. Figure 3 shows the agarose gel of blas ${ }_{S H}$ after PCR (Table 5).

\section{Discussion}

4.1. Prevalence of Pathogens in the Samples. Of the 130 samples analyzed, we were able to isolate 63 bacterial strains, all Gram-negative bacilli. The kitchen environment samples contained $36.50 \%$ (23/63) of the isolated bacterial strains, followed by external environmental samples (33.33\%) (21/63), whereas the samples from food products were $30.15 \%$ (19/63). In addition, $47.61 \%$ of the bacteria isolated from cooking samples are ESBL producers. These results show that there is a high risk of contamination of food products in these kitchen environments if the appropriate practice of hygiene is not maintained. A report from a study on ESBL-producing Enterobacteriaceae isolated from food prepared in the kitchen of a hospital center [26] showed that $8.04 \%$ of foods from the hospital kitchen were contaminated with ESBL-producing strains. This low prevalence reflects the minimum respect of hygiene rules in the kitchen of the hospital. Thus, the risk of contamination was lower in this environment, but this should not be extrapolated to the community kitchen environment, where safety standards are probably less rigorously respected [27].

Of 48 external environmental samples (wastewater and sediment), $42.85 \% \%$ of the strains produced ESBL. This proportion is relatively lower than that obtained by [28], where $52.69 \%$ of the ESBL-producing Enterobacteriaceae were reported. However, these results are relatively high than those obtained by [29], where $15.47 \%$ of the ESBLproducing bacteria were noted. These different results show that there is a real problem of environmental contamination in Benin. Several studies have been conducted on the isolation of ESBL-producing E. coli from rivers. The human and animal ESBL-producing E. coli in various river waters may be related to the nature of their watersheds, the intensity of 
TABLE 4: Distribution of virulence-associated genes in different isolates.

\begin{tabular}{|c|c|c|c|c|c|c|c|}
\hline \multirow[t]{2}{*}{ Isolates } & \multirow[t]{2}{*}{ No. } & \multicolumn{6}{|c|}{ No. (\%) of virulence-associated genes } \\
\hline & & Iss & fimH & Biofilm & PapC & stx1 & stx2 \\
\hline Acinetobacter baumanii & 4 & 0 & 0 & 0 & 0 & 0 & 0 \\
\hline Pseudomonas horyzihabitans & 6 & 0 & 0 & 0 & 0 & 0 & 0 \\
\hline Pseudomonas aeruginosa & 5 & 0 & $1(20)$ & 0 & 0 & 0 & 0 \\
\hline Pseudomonas fluorescens & 1 & 0 & 0 & 0 & 0 & 0 & 0 \\
\hline Klebsiella pneumonia & 4 & 0 & 0 & 0 & 0 & 0 & 0 \\
\hline Klebsiella terrigena & 1 & 0 & 0 & 0 & 0 & 0 & 0 \\
\hline Klebsiella ornithynolitica & 1 & 0 & 0 & 0 & 0 & 0 & 0 \\
\hline Serratia marcescens & 2 & 0 & 0 & 0 & 0 & 0 & 0 \\
\hline Serratia liquefasciens & 1 & 0 & 0 & 0 & 0 & 0 & 0 \\
\hline Chryseomoas luteola & 10 & 0 & 0 & 0 & 0 & 0 & 0 \\
\hline Enterobacter aerogenes & 3 & 0 & $1(33.33)$ & 0 & 0 & 0 & 0 \\
\hline Enterobacter cloacae & 6 & 0 & 0 & 0 & 0 & 0 & 0 \\
\hline Stenotrophomonas maltophilia & 2 & 0 & 0 & 0 & 0 & 0 & 0 \\
\hline Escherichia coli & 6 & 0 & $5(83.33)$ & 0 & 0 & 0 & 0 \\
\hline Shigella spp & 1 & 0 & 0 & 0 & 0 & 0 & 0 \\
\hline Pantoea spp & 1 & 0 & 0 & 0 & 0 & 0 & 0 \\
\hline Burkholderia cepacian & 1 & 0 & 0 & 0 & 0 & 0 & 0 \\
\hline Klebsiella Spp & 4 & 0 & 0 & 0 & 0 & 0 & 0 \\
\hline Citrobacter freundii & 2 & 0 & 0 & 0 & 0 & 0 & 0 \\
\hline Citrobacter diversus & 1 & 0 & 0 & 0 & 0 & 0 & 0 \\
\hline Enterobacter gergoviae & 1 & 0 & 0 & 0 & 0 & 0 & 0 \\
\hline Total & 63 & 0 & $7(11.11)$ & 0 & 0 & 0 & 0 \\
\hline
\end{tabular}

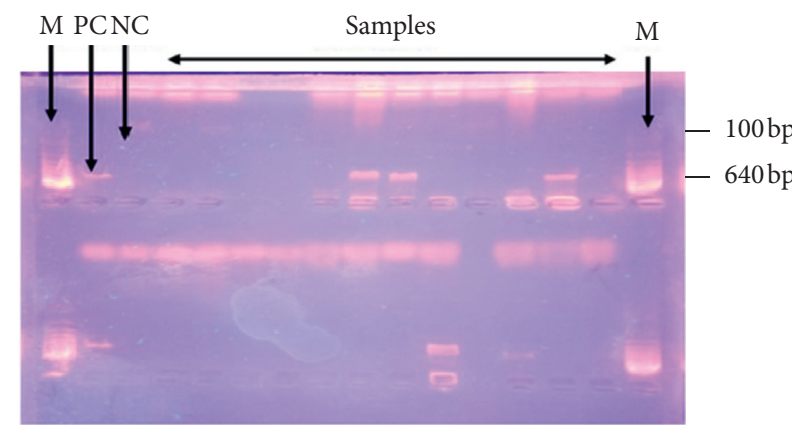

$\mathrm{M}=$ Size maker $\mathrm{PC}=$ Positive control $\mathrm{NC}=$ Negative control

(a)

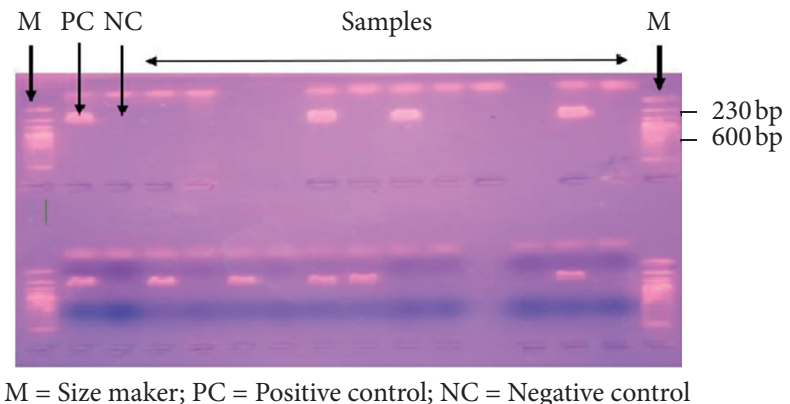

(b)

Figure 3: (a) Agarose gel of fimH gene (640 bp) after PCR. (b) Agarose gel of blashv gene (230 bp) after PCR.

antibiotic use, and the relative degree of fecal contamination by humans and animals. Clonal groups similar to those found in human infections have also been isolated from contaminated rivers adjacent to large cities [30, 31].

The prevalence of ESBL-producing bacteria was 13.75\% from fecal animal samples. Also, this same proportion was obtained in piglet feces in India [32]. These results reflect the risk of contamination of slaughter meat and food products of animal origin. Of the 43 food samples, there is a prevalence of $9.52 \%$ of ESBL-producing bacterial strains. This result is relatively small compared to the $20.75 \%$ of Gram-negative Bacillus (GNB) ESBL producers obtained by [33] from hospital samples in Benin.

4.2. Antimicrobial Resistance. In this study, 63 bacterial strains from 21 species were isolated. The most identified bacterial species is C. luteola (10/63). Antibiotic susceptibility analysis showed high resistance of bacterial isolates to penicillin, cephalosporins, and aztreonam. This high resistance of the isolates coincides with the results obtained by [28] that was conducted on environmental samples and food in Spain. In addition, it was noted that the isolates showed significant resistance to $\beta$-lactamase inhibitors such as amoxicillin + clavulanic acid (70.39\%). These results coincide with those from [34], where resistance of strains to betalactamase inhibitors is noted. This suggests that there is an increasing need to encourage the use of alternative betalactamase inhibitors. For the multidrug resistance analysis of bacterial isolates, $10(16.81 \%)$ of the isolates were resistant to at least three different families of antibiotics. These results further emphasize the problem of multidrug-resistant bacteria in the environment which may threaten both human and animal health. The resistance of a high proportion of 
TABLE 5: Distribution of ESBL genes in different isolates.

\begin{tabular}{|c|c|c|c|c|c|c|c|}
\hline \multirow{2}{*}{ Isolates } & \multicolumn{7}{|c|}{ ESBL genes (\%) } \\
\hline & No & $\mathrm{Bla}_{\mathrm{TEM}}$ & $\mathrm{Bla}_{\mathrm{SHV}}$ & Bla $_{\text {CTX-M1 }}$ & Bla $_{\text {CTX-M2 }}$ & Bla $_{\text {CTX-M9 }}$ & Bla $_{\text {CTX-M15 }}$ \\
\hline Acinetobacter baumanii & 4 & 0 & 0 & 0 & 0 & 0 & 0 \\
\hline Pseudomonas horyzihabitans & 6 & 0 & 0 & 0 & 0 & 0 & 0 \\
\hline Pseudomonas aeruginosa & 5 & 0 & $5(100)$ & 0 & 0 & 0 & 0 \\
\hline Pseudomonas fluorescens & 1 & 0 & $1(100)$ & 0 & 0 & 0 & 0 \\
\hline Klebsiella pneumonia & 4 & 0 & $3(75)$ & 0 & 0 & 0 & 0 \\
\hline Klebsiella terrigena & 1 & 0 & 0 & 0 & 0 & 0 & 0 \\
\hline Klebsiella ornithynolitica & 1 & 0 & 0 & 0 & 0 & 0 & 0 \\
\hline Serratia marcescens & 2 & 0 & $1(50)$ & 0 & 0 & 0 & 0 \\
\hline Serratia liquefasciens & 1 & 0 & 0 & 0 & 0 & 0 & 0 \\
\hline Chryseomoas luteola & 10 & 0 & 0 & 0 & 0 & 0 & 0 \\
\hline Enterobacter aerogenes & 3 & 0 & $3(100)$ & 0 & 0 & 0 & 0 \\
\hline Enterobacter cloacae & 6 & 0 & $3(50)$ & 0 & 0 & 0 & 0 \\
\hline Stenotrophomonas maltophilia & 2 & 0 & $1(50)$ & 0 & 0 & 0 & 0 \\
\hline Escherichia coli & 6 & 0 & $2(33.33)$ & 0 & 0 & 0 & 0 \\
\hline Shigella $\operatorname{spp}$ & 1 & 0 & $1(100)$ & 0 & 0 & 0 & 0 \\
\hline Pantoea spp & 1 & 0 & $1(100)$ & 0 & 0 & 0 & 0 \\
\hline Burkholderia cepacian & 1 & 0 & 0 & 0 & 0 & 0 & 0 \\
\hline Klebsiella Spp & 4 & 0 & 0 & 0 & 0 & 0 & 0 \\
\hline Citrobacter freundii & 2 & 0 & 0 & 0 & 0 & 0 & 0 \\
\hline Citrobacter diversus & 1 & 0 & 0 & 0 & 0 & 0 & 0 \\
\hline Enterobacter gergoviae & 1 & 0 & 0 & 0 & 0 & 0 & 0 \\
\hline Total & 63 & 0 & $21(33.33)$ & 0 & 0 & 0 & 0 \\
\hline
\end{tabular}

bacterial strains to carbapenems (Imipenem (IPM): 25.39\%; Ertapenem (ETP): 61.90\%) is a serious public health problem, as these antibiotics are the most effective of the beta-lactams against Gram-positive and Gram-negative bacteria, with a broad spectrum of activity [35].

4.3. ESBL and Virulence-Associated Genes Detection. Phenotypic detection of bacterial ESBL-producing strains was carried out by the double synergy technique. Only 21/63 of isolates were ESBL-producing; a correlation $(r=1)$ was noted between the two phenotypic detection techniques of ESBL-producing isolates. This involves the culture of samples on ChromID ${ }^{\text {TM }}$ ESBL agar and the search for the double synergistic effect during the antibiotic susceptibility test. The presence of the bla $\mathrm{SHV}_{\mathrm{SH}}$ gene in the genome of $33.33 \%$ of isolates confirms this correlation. $P$. aeruginosa (100\%) was the most predominant among these strains with ESBL genes. However, among the ESBL genes sought, only the bla $\mathrm{SHV}_{\mathrm{S}}$ gene was found in the ESBL-positive isolates. The bla carrying organisms have also been detected in a variety of environmental and food samples [36]. Despite the high cefotaxime resistance observed, the bacterial strains were negative to bla $\mathrm{CTX}_{\mathrm{M}}$, suggesting that other genes may be involved in the resistance mechanism.

The search for virulence genes also showed the presence of a single virulence gene in the isolates; the fim $\mathrm{H}$ gene, also known as the fimbriae adhesion gene type 1 (fim $\mathrm{H})$, recorded the prevalence of $11.11 \%$ in this study. E. coli $(83.33 \%)$ was the most predominant bacterial among this group. It is believed that fim $\mathrm{H}$ contributes to the protection of E. coli from heterophilous hosts [37]. Its role in the virulence of Avian Pathogenic E. coli strains remains controversial and is the subject of conflicting reports [38]. Other studies found higher occurrences of the fim $\mathrm{H}$ gene, particularly those from [39], which found a prevalence of 98.1\% among 524 Avian Pathogenic E. coli isolates.*

\section{Conclusion}

This study allowed us to characterize the multidrug resistance, virulence, and ESBL production of bacterial strains isolated from the external environment, food products, and community kitchen samples. Only $33.33 \%$ of the isolates were ESBL-positive and $11.11 \%$ harboured the virulence fim $\mathrm{H}$ gene. Only the bla $\mathrm{S}_{\mathrm{SHV}}$ gene was present in the genome of isolated strains. The community kitchen samples showed a high prevalence of ESBL-producing bacteria and fim $\mathrm{H}$ gene. This raises the problem of non-compliance with hygiene rules in community kitchen.

\section{Limitations}

This study presents some limitations. We did not identify

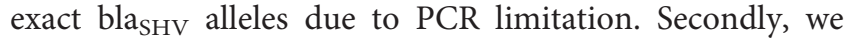
could not confirm carbapenem resistance genotypically. In addition, we could not detect other $\beta$-lactamase genes and virulence factors that may be present. Future studies including whole genome sequencing could help to address these limitations.

\section{Data Availability}

All data generated or analyzed during this study are included in this published article. 


\section{Disclosure}

The kitchen samples were collected after gaining the informed consent of the head of the household.

\section{Conflicts of Interest}

The authors declare that they have no conflicts of interest.

\section{Authors' Contributions}

Victorien Dougnon, Vincentia Marie Camille Houssou, Jerrold Agbankpe, Birikissou Bouraima, Esther Deguenon, Eugénie Anago, Martin Pépin Aïna, and Lamine BabaMoussa wrote the protocol. Victorien Dougnon, Vincentia Marie Camille Houssou, Chimène Nanoukon, Jibril Mohammed, Birikissou Bouraima, Esther Deguenon, Martin Pépin Aïna, Kafayath Fabiyi, Marie Hidjo, Hornel Koudokpon, and Fidélia Djegui processed the samples. Victorien Dougnon and Jerrold Agbankpe did the statistical analyses. Victorien Dougnon, Vincentia Marie Camille Houssou, Jerrold Agbankpe, Chimène Nanoukon and Jibril Mohammed wrote the draft of the manuscript. Victorien Dougnon, Jerrold Agbankpe, and Lamine Baba-Moussa reviewed the manuscript. All authors read and approved the final version of the manuscript.

\section{Acknowledgments}

The authors are grateful to Dr Kaisa HAUKKA (Department of Microbiology, University of Helsinki) who reviewed this manuscript. They also thank the Minister of the Living Environment and Sustainable Development in Benin, his Excellency his Excellency M. José TONATO and all his staff. They are also grateful to the Cordinator of The Regional Disease Surveillance Systems Enhancement (REDISSE) Project in West Africa, Madam Fidélia SESSOU HINSON and her staff in Benin for the support.

\section{References}

[1] World Health Organization, Antimicrobial Resistance: Global Report on Surveillancehttp://www.who.int/drugresistance/ documents/surveillancereport/en/, World Health Organization, Geneva, Switzerland, 2019, http://www.who.int/ drugresistance/documents/surveillancereport/en/.

[2] J. O’Neill, “Tackling drug-resistant infections globally: final report and recommendations," 2019, http://amr-review.org/ sites/default/files/160518_Final\%20paper_with\%20cover.pdf.

[3] D. V. De Oliveira and S. T. Van Der Sand, "Phenotypic tests for the detection of $\beta$-lactamase-producing enterobacteriaceae isolated from different environments," Current Microbiology, vol. 73, no. 1, pp. 132-138, 2016.

[4] S. Yamasaki, T. D. Le, M. Q. Vien, C. Van Dang, and Y. Yamamoto, "Prevalence of extended-spectrum $\beta$-lactamase-producing Escherichia coli and residual antimicrobials in the environment in Vietnam," Animal Health Research Reviews, vol. 18, no. 2, pp. 128-135, 2018.

[5] L. Benjamin, E. R. Atwill, M. Jay-Russell et al., "Occurrence of generic Escherichia coli, E. coli $\mathrm{O} 157$ and Salmonella spp. in water and sediment from leafy green produce farms and streams on the Central California Coast," International Journal of Food Microbiology, vol. 165, no. 1, pp. 65-76, 2013.

[6] E. Ojer-Usoz, D. González, A. I. Vitas et al., "Prevalence of extended-spectrum $\quad \beta$-lactamase-producing enterobacteriaceae in meat products sold in Navarra, Spain," Meat Science, vol. 93, no. 2, pp. 316-321, 2013.

[7] C. Kürekci, M. Aydin, M. Yipel, M. Katouli, and A. Gündoğdu, "Characterization of extended spectrum $\beta$-lactamase (ESBL)-producing Escherichia coli in Asi (Orontes) River in Turkey," Journal of Water and Health, vol. 15, no. 5, pp. 788-798, 2017.

[8] E. Ruppé, L. Armand-Lefèvre, C. Estellat et al., "High rate of acquisition but short duration of carriage of multidrug-resistant enterobacteriaceae after travel to the tropics," Clinical Infectious Diseases, vol. 61, no. 4, pp. 593-600, 2015.

[9] M. Fernández-Reyes, D. Vicente, M. Gomariz et al., "High Rate of fecal carriage of extended-spectrum- $\beta$-lactamaseproducing Escherichia coli in healthy children in Gipuzkoa, Northern Spain," Antimicrobial Agents and Chemotherapy, vol. 58, no. 3, pp. 1822-1824, 2014.

[10] S. M. G. Al-Mayahie, "Phenotypic and genotypic comparison of ESBL production by vaginal Escherichia coli isolates from pregnant and non-pregnant women," Annals of Clinical Microbiology and Antimicrobials, vol. 12, pp. 1-7, 2013.

[11] K. Bush and J. F. Fisher, "Epidemiological expansion, structural studies, and clinical challenges of new $\beta$-lactamases from gram-negative bacteria," Annual Review of Microbiology, vol. 65, no. 1, pp. 455-478, 2011.

[12] Z. Hojati, B. Zamanzad, M. Hashemzadeh, R. Molaie, and A. Gholipour, "The fim $\mathrm{H}$ gene in uropathogenic Escherichia coli strains isolated from patients with urinary tract infection," Jundishapur Journal of Microbiology, vol. 8, pp. 1-4, 2015.

[13] R. Dehbanipour, S. Rastaghi, M. Sedighi, N. Maleki, and J. Faghri, "High prevalence of multidrug-resistance uropathogenic Escherichia coli strains, Isfahan, Iran," Journal of Natural Science, Biology, and Medicine, vol. 7, no. 1, pp. 22-26, 2016.

[14] H. R. Jalali, A. Pourbakhsh, F. Fallah, and G. Eslami, "Genotyping of virulence factors of uropathogenic Escherichia coli by PCR," Novelty in Biomedicine, vol. 3, no. 4, pp. 177-181, 2015.

[15] H. Ghazvini, K. Taheri, E. Edalati, M. Sedighi, and S. Mirkalantari, "Virulence factors and antimicrobial resistance in uropathogenic Escherichia coli strains isolated from cystitis and pyelonephritis," Turkish Journal of Medical Sciences, vol. 49, pp. 361-367, 2019.

[16] N. Singhal, M. Kumar, and J. S. Virdi, "Molecular analysis of $\beta$-lactamase genes to understand their differential expression in strains of Yersinia enterocolitica biotype 1A," Scientific Reports, vol. 4, p. 5270, 2014.

[17] E. Anago, L. Ayi-Fanou, C. D. Akpovi et al., "Antibiotic resistance and genotype of beta-lactamase producing Escherichia coli in nosocomial infections in Cotonou, Benin," Annals of Clinical Microbiology and Antimicrobials, vol. 14, p. 5, 2015.

[18] D. Affolabi, F. Sogbo, G. Laleye et al., "Rapid detection of extended spectrum- $\beta$-lactamase-producing enterobacteriaceae in blood cultures using the ESBL NDP test in Cotonou, Benin," Journal of Medical Microbiology, vol. 66, pp. 884-887, 2017.

[19] T. V. Dougnon, E. Déguénon, L. Fah et al., "Traditional treatment of human and animal salmonelloses in Southern Benin: knowledge of farmers and traditherapists," Veterinary World, vol. 10, no. 6, pp. 580-592, 2017. 
[20] 2018 Antibiogram Commitee of the French Society of Microbiology, 2018 Recommendations, 2018.

[21] Clinical and Laboratory Standards Institute (CLSI), Performance Standards for Antimicrobial Susceptibility Testing. $25^{\text {th }}$ informational Supplement, CLSI, Wayne, PA, USA, 2015.

[22] A. M. Ahmed, Y. Motoi, M. Sato et al., "Zoo animals as reservoirs of gram-negative bacteria harboring integrons and antimicrobial resistance genes," Applied and Environmental Microbiology, vol. 73, pp. 6686-6690, 2007.

[23] M. Oliveira, F. R. Dias, and C. Pomba, "Biofilm and fluoroquinolone resistance of canine Escherichia coli uropathogenic isolates,” BMC Research Notes, vol. 7, p. 499, 2014.

[24] M. Krizman, J. A. Avgustin, I. Zdovc et al., "Antimicrobial resistance and molecular characterization of extended-spectrum $\beta$-lactamases and other Escherichia coli isolated from food of animal origin and human intestinal isolates," Journal of Food Protection, vol. 80, no. 1, pp. 113-120, 2017.

[25] N. Singhal, N. S. Singh, A. K. Maurya, and J. S. Virdi, "Virulence-associated traits and in vitro biofilm-forming ability of Escherichia coli isolated from a major river traversing Northern India," Environmental Science and Pollution Research, vol. 26, pp. 21304-21311, 2019.

[26] A. J. Stewardson, G. Renzi, N. Maury et al., "Extended spectrum $\beta$-lactamase-producing enterobacteriaceae in hospital food: a risk assessment," Infection Control \& Hospital Epidemiology, vol. 35, no. 4, pp. 375-383, 2014.

[27] E. C. Redmond and C. J. Griffith, "Consumer food handling in the home: a review of food safety studies," Journal of Food Protection, vol. 66, pp. 130-161, 2003.

[28] E. Ojer-Usoz, D. González, and A. I. Vitas, "Clonal diversity of ESBL-producing Escherichia coli isolated from environmental, human and food samples," International Journal of Environmental Research and Public Health, vol. 14, no. 7, p. 676, 2017.

[29] Y. Y. Hu, J. C. Cai, H. W. Zhou et al., "Molecular typing of CTX-M-producing Escherichia coli isolates from environmental water, swine feces, specimens from healthy humans, and human patients," Applied and Environmental Microbiology, vol. 79, pp. 5988-5996, 2013.

[30] M. Colomer-Lluch, A. Mora, C. López et al., "Detection of quinolone-resistant Escherichia coli isolates belonging to clonal groups $\mathrm{O}_{25} \mathrm{~b}: \mathrm{H}_{4}-\mathrm{B}_{2}-\mathrm{ST}_{131}$ and $\mathrm{O}_{25} \mathrm{~b}: \mathrm{H}_{4}-\mathrm{D}-\mathrm{ST}_{69}$ in raw sewage and river water in Barcelona, Spain," Journal of Antimicrobial Chemotherapy, vol. 68, pp. 758-765, 2012.

[31] K. Zurfluh, H. Hächler, M. Nüesch-Inderbinen, and R. Stephan, "Characteristics of extended spectrum $\beta$-lactamase and carbapenemase producing enterobacteriaceae isolates from rivers and lakes in Switzerland," Applied and Environmental Microbiology, vol. 79, pp. 3021-3026, 2013.

[32] K. R. Nirupama, O. R. Vinodh Kumar, B. S. Pruthvishree et al., "Molecular characterisation of bla OxA-48 carbapenemase-, extended-spectrum $\beta$-lactamase- and Shiga toxin-producing Escherichia coli isolated from farm piglets in India," Journal of Global Antimicrobial Resistance, vol. 13, pp. 201-205, 2018.

[33] W. Moussé, H. Sina, I. A. Mama-Sirou et al., "Antibiotic resistance and production of extended spectrum $\beta$-lactamases by clinical gram-negative bacteria in Benin," Journal of Advances in Microbiology, vol. 18, no. 2, pp. 1-13, 2019.

[34] D. González, E. Gallagher, T. Zúñiga, J. Leiva, and A. I. Vitas, "Prevalence and characterization of $\beta$-lactamase-producing enterobacteriaceae in healthy human carriers," International Microbiology, vol. 23, no. 2, pp. 171-177, 2019.
[35] G. Meletis, "Carbapenem resistance: overview of the problem and future perspectives," Therapeutic Advances in Infectious Disease, vol. 3, pp. 15-21, 2016.

[36] A. S. Singh, M. Lekshmi, S. Prakasan, B. B. Nayak, and S. Kumar, "Multiple antibiotic-resistant, extended spectrum$\beta$-lactamase (ESBL)-Producing enterobacteria in fresh seafood," Microorganisms, vol. 5, p. 53, 2017.

[37] M. Mellata, M. Dho-Moulin, C. M. Dozois et al., "Role of virulence factors in resistance of avian pathogenic Escherichia coli to serum and inpathogenicity," Infection and Immunity, vol. 71, pp. 536-540, 2003.

[38] G. Li, C. Laturnus, C. Ewers, and L. H. Wieler, "Identification of genes required foravian Escherichia coli septicemia by signature-tagged mutagenesis," Infection and Immunity, vol. 73, no. 5, pp. 2818-2827, 2005.

[39] K. E. Rodriguez-Siek, C. W. Giddings, C. Doetkott, T. J. Johnson, M. K. Fakhr, and L. K. Nolan, "Comparison of Escherichia coli isolates implicated in humanurinary tract infection andavian colibacillosis," Microbiology, vol. 151, pp. 2097-2110, 2005. 